\title{
選択的経静脈塞栓術が可能な横S状静脈洞部硬膜動静哌瘻
}

清末一路 ${ }^{1)}$

\section{Transverse-sigmoid sinus dural arteriovenous fistula can be treated by selective transvenous embolization}

\author{
Hiro KIYOSUE1)
}

1) Department of Radiology, Oita University Faculty of Medicine

1）大分大学医学部 放射線科

<連絡先：=879-5593 大分県由布市挾間町医大が丘1-1 E-mail : hkiyosue@med.oita-u.ac.jp>

(Received June 20, 2007 : Accepted August 11, 2007)

横・S 状静脈洞部の硬膜静脈洞瘻に対する経静脈塞栓 術は通常Cognard type II, type IIIの硬膜動静脈瘻でか つ罹患部の静脈洞を閉塞可能な症例に対し行われる11. しかしCognard type Iであっても，時に短絡部が静脈 洞と分離可能で静脈洞を温存して選択的に塞栓可能な症 例も存在する.

\section{症 例}

患 者 : 72歳女性

主 訴: 左耳鳴

病 歴：上記主訴にて近医耳鼻科を受診するも異常ない といわれ，放置していた，肝腫瘤の精査にて入院時に，
同症状にて頭部MRAを撮像したところ左S状静脈洞部に 硬膜動静脈瘻を指摘される.

身体所見：左耳後部にBruitを聴取する，その他には異 常所見なし.

血管造影所見 : 左 $\mathrm{S}$ 状静脈洞部に, 左中硬膜動脈や後頭 動脈より主に供血される動静脈瘻を認める (Fig.1)。 シ ヤント血流の大部分は順行性に内頸静脈へと流出し, 一 部下錐体静脈洞を逆流し, 海綿静脈洞や対側の下垂体静 脈洞へと流出する. 注意して観察すると短絡部は $S$ 状静 脈洞の上内側部のvenous pouchに集中していることがわ かる. 左外頸動脈の3D-DSA横断再構成画像では, feeding arteryがS状静脈洞の上内側に存在するvenous

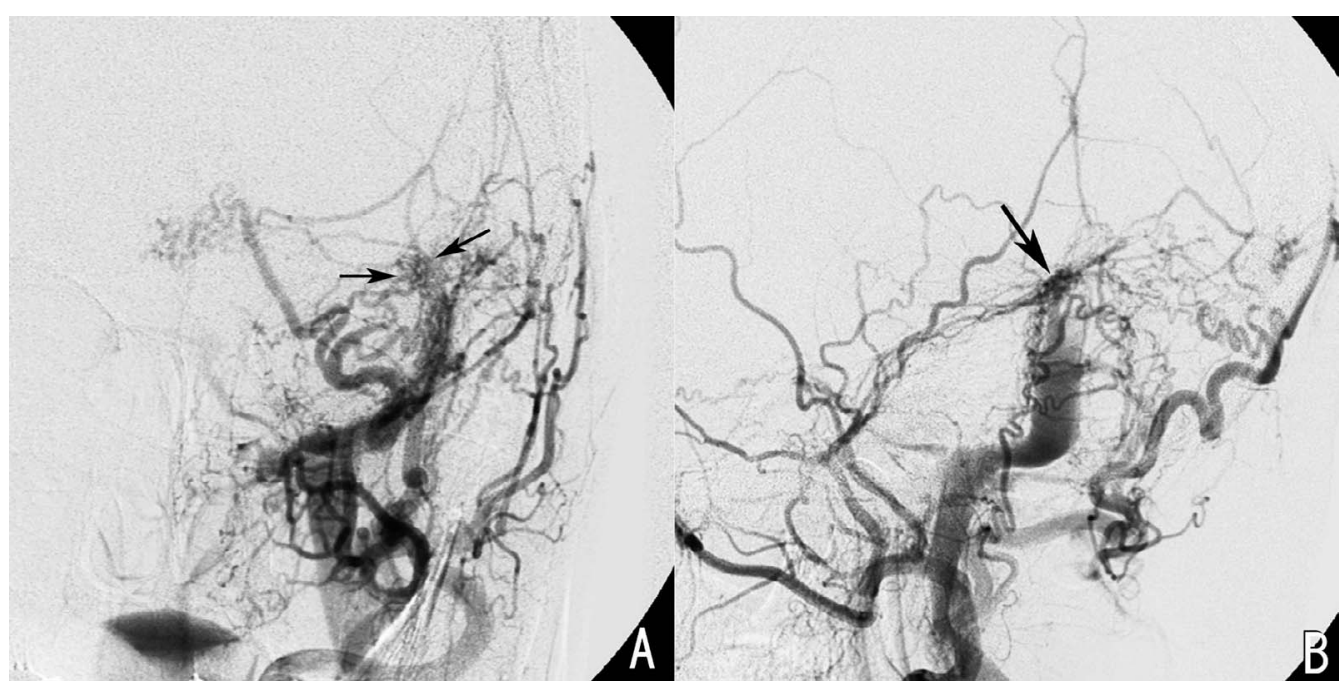

Fig.1 : Frontal (A) and lateral (B) views of left external carotid angiogram showing a dural arteriovenous fistula of the left sigmoid sinus fed by the multiple branches of the left external carotid artery. Multiple feeding arteries shunt into a small venous pouch (arrows) located superiormedially to the sigmoid sinus. 


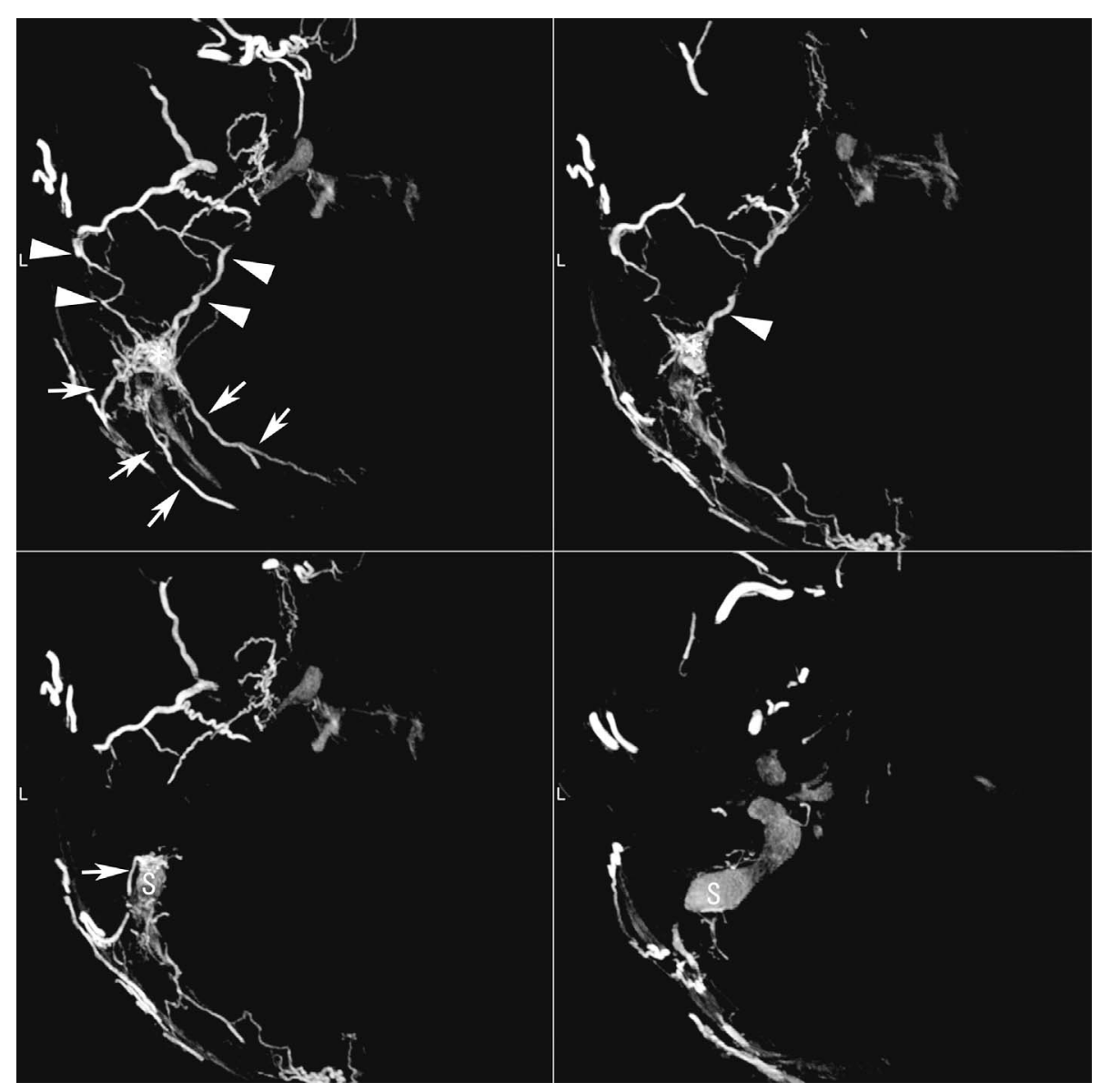

Fig.2 : Sequential axial MIP images of 3D-DSA demonstrating that transosseous branches of the occipital artery (white arrowheads) and posterior branches of the middle menigeal artery (white arrowheads) shunt into a small venous pouch (asterisk) which drains into the sigmoid sinus (S).

pouchに集中している像が明瞭に描出される（Fig.2）. 有症状であり，横S状静脈洞部の硬膜動静脈瘻は自然消 退の頻度が低いこと，将来的に流出路の狭窄性変化をき たし脳表静脈への逆流やうっ血などを起こす危険性を有 すること，かつ前述のvenous pouchの閉塞により根治可 能と考えられたため選択的経静脈塞栓術が施行された。

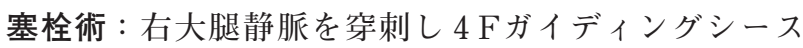
(メデイキット，東京）を挿入，左頸静脈球に留置した。

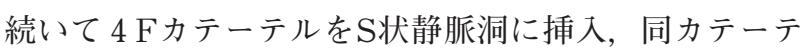
ルを通しマイクロカテーテル (Excelsior, Boston Scientific Japan, Tokyo) を短絡部のvenous pouchに進 めた．左外頸動脈造影と同時にマイクロカテーテルから の静脈造影を行い，マイクロカテーテル先端の位置を確 認した後に離断型コイル (EDC : カネカメデイカル, 東京） 4 個を用い短絡部のvenous pouchを選択的に塞栓 した（Fig.3）。塞栓術後の総頸動脈造影では動静脈瘻は 消失し，S状静脈洞を介する正常な還流は保たれていた
(Fig.4) .

\section{考察}

Cognard type 1 の頭蓋内硬膜動静脈瘦は通常耳鳴など の軽度な症状を示し，神経脱落症状をきたすことは非常 に稀である．皮質静脈への逆流を伴わない良性頭蓋内硬 膜動静脈瘻の保存的治療による長期予後に関して Satomiらの報告では，平均27.9月の観察期間に打いて 112例のうち110例では増悪はなく，2例（2％）の症 例で皮質静脈への逆流が出現したとされる ${ }^{8)}$. よって, Type 1 硬膜動静脈瘻の治療法としては一般的には経過 観察または低侵襲である流入動脈塞栓や放射線治療など の保存的治療が扎こなわれる。しかし，頻度は少ないが 流出路の狭窄・閉塞性変化の進行に伴い, 皮質静脈の逆 流や神経症状の出現をきたす症例も存在することから, 本例のごとく安全に動静脈瘻を根治できることが期待で きる場合には選択的塞栓術の適応が考慮される. 

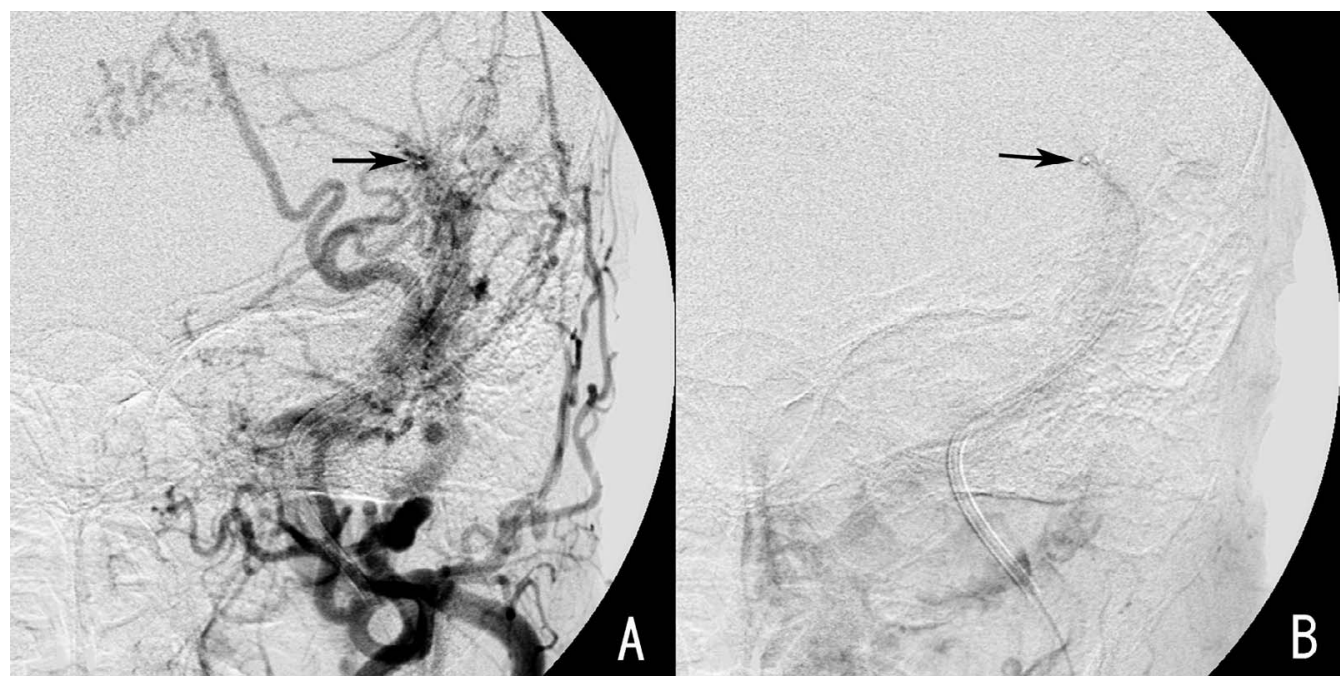

Fig.3 : The left external carotid angiogram (A) and a consequent injection via the microcatheter (B) showing the tip of the microcatheter exactly located in the shunted venous pouch.
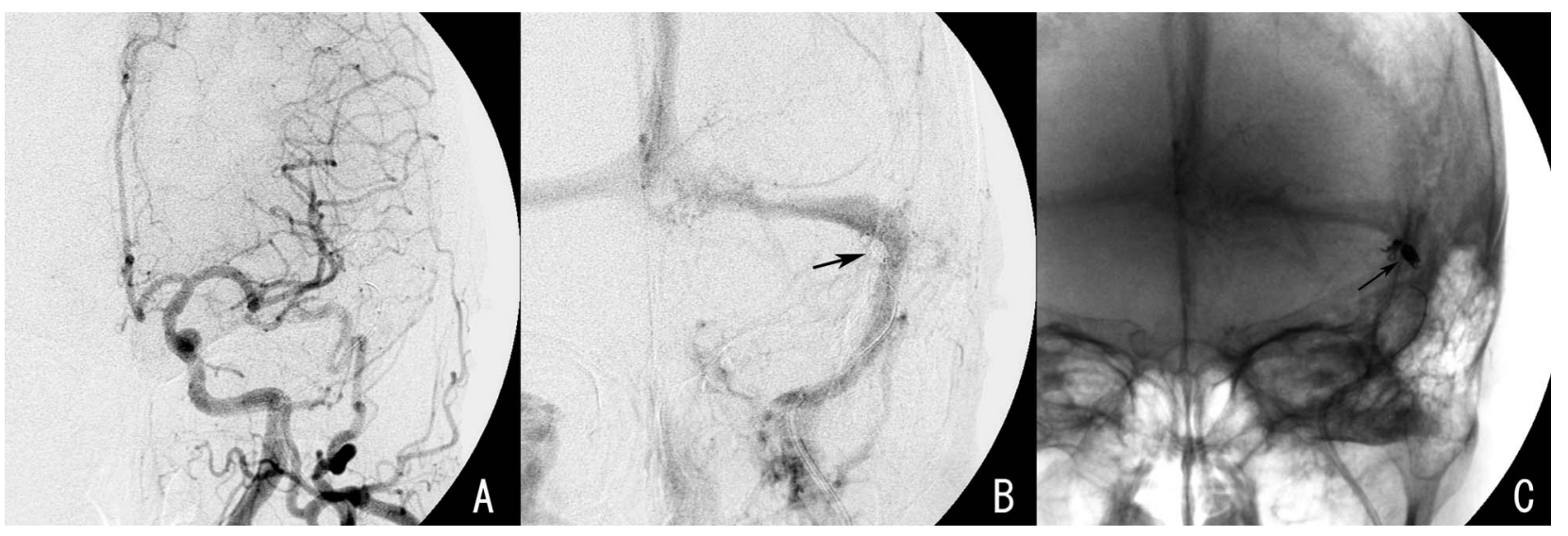

Fig.4: Left common carotid angiogram at arterial phase (A) and venous phase (B) immediately after transvenous embolization showing disappearance of the AVF with preserved blood flow of the sigmoid sinus. Fluoroscopic image (C) showing coil mass (arrow) adjacent to the sigmoid sinus.

静脈洞を温存し短絡部のみを閉塞する選択的経静脈塞 栓術に関しては，過去の文献的報告は少ないが，日常臨 床においては時に経験する ${ }^{4-7)}$ 。短絡部のvenous pouchの 存在部位に関しては静脈洞壁内に存在，静脈洞の傍に parasinusとして存在，静脈洞に隔壁が存在するなどが 考えられ，いずれの場合も起こりえる2-7)。本例の場合 $\mathrm{S}$ 状静脈洞の内側にvenous pouchが存在し，塞栓後も同部 の静脈洞の短径は正常であり, parasinusとして存在し ているように思われる。診断に関してはまずこのような タイプの硬膜動静脈瘻が存在することに留意して血管造 影像を注意して観察することが基本である．3D-DSA再 構成画像は短絡部を明瞭に描出することが可能で，術前 評価に有用である。またMRA原画像にても多くの場合 短絡部の評価は可能である。選択的な短絡部の塞栓術は
横・S 状静脈洞部硬膜動静脈瘻に対する通常の経静脈的 静脈洞塞栓術の際にも有用であり，罹患部の静脈洞に単 にコイルを留置するのではなく，できるだけ短絡部の pouchに選択的に密にコイルを留置することによってよ り効果的かつ安全に治療が行えると考える。治療に打け る留意点としては広い静脈洞から小さなvenous pouchに マイクロカテーテルを挿入して塞栓を行うことから，カ テーテルの挿入やコイル挿入の際にカテーテルが逸脱し やすいので，マイクロカテーテルのサポートが重要であ る. 我々の施設では本例のごとく通常ガイデイングとし

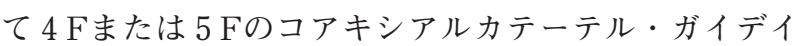
ングシースの組み合わせを用いて治療を行っている。 そ の他の治療法としてn-butyl-2-cyanoacrylateやOnyxなど を用いた経動脈塞栓術や経動脈塞栓術と定位放射線治療 
の組み合わせなどが考えられるが，簡便性や，確実性， 安全性などから可能な場合には選択的経静脈塞栓術を第 1 選択とすべきと考える。経静脈塞栓術が不成功の場合 または短絡が残存する場合には前述の他の治療法が考慮 される，同治療法の潜在的な問題点として，治療後に塞 栓部近傍に新たに硬膜動静脈瘻が発生することがある ${ }^{4)}$. 同部周囲の硬膜や静脈洞の静脈圧や血管新生因子のバラ ンスの不均衡などが再発の誘引となると推測されるが, その原因はいまだ明らかではない9-11)。いずれにせよ選 択的塞栓術を行った後は，近傍からの再発に関して注意 して経過観察を行うことが重要である。

\section{文 献}

1) Cognard C, Gobin YP, Pierot L, et al: Cerebral dural arteriovenous fistulas: clinical and angiographic correlation with a revised classification of venous drainage. Radiology 194:671-680, 1995.

2 ) Fukai J, Terada T, Kuwata T, et al: Transarterial intravenous coil embolization of dural arteriovenous fistula involving the superior sagittal sinus. Surg Neurol 55:353-358, 2001.

3 ) Hamada Y, Goto K, Inoue T, et al: Histopathological aspects of dural arteriovenous fistulas in the transversesigmoid sinus region in nine patients. Neurosurgery 40:452-458, 1997.

4 ) Kiyosue H, Tanoue S, Okahara M, et al: Recurrence of dural arteriovenous fistula in another location after selective transvenous coil embolization: Report of two cases. AJNR 23:689-692, 2002.

5 ) Mironov A: Selective transvenous embolization of dural fistulas without occlusion of the dural sinus. AJNR 19:389-391, 1998.

6 ) Ohtakara K, Murao K, Kawaguchi K, et al: Selective transvenous liquid embolization of a Type 1 dural arteriovenous fistula at the junction of the transverse and sigmoid sinuses. Case report. J Neurosurg 92:1045-1049, 2000.

7 ) Piske RL, Campos CM, Chaves JB, et al: Dural sinus compartment in dural arteriovenous shunts: a new angioarchitectural feature allowing superselective transvenous dural sinus occlusion treatment. AJNR 26:1715-1722, 2005.

8 ) Satomi J, van Dijk JM, Terbrugge KG, et al: Benign cranial dural arteriovenous fistulas: outcome of conservative management based on the natural history of the lesion. J Neurosurg 97:67-70, 2002.

9 ) Terada T, Higashida RT, Halbach VV, et al: The effect of oestrogen on the development of arteriovenous fistulae induced by venous hypertension in rats. Acta Neurochir (Wien) 140:82-86, 1998.

10) Uranishi R, Nakase H, Sakaki T: Expression of angiogenic growth factors in dural arteriovenous fistula. J Neurosurg 91:781-786, 1999.

11) Ward NL, Haninec AL, Van Slyke P, et al: Angiopoietin-1 causes reversible degradation of the portal microcirculation in mice: implications for treatment of liver disease. Am J Pathol 165:889-899, 2004. 